\section{artelogie}

\section{Artelogie}

Recherche sur les arts, le patrimoine et la littérature de l'Amérique latine

12 | 2018

Idiosyncrasie de l'indigénisme en Amérique latine.

Pluralité des sources et des appropriations extra-

latino-américaines

\title{
The Display of the 'Indigenous' - Collecting and Exhibiting 'Indigenous' Artifacts in Mexico, 1920-1940
}

\section{Miriam Oesterreich}

\section{(2) OpenEdition \\ Journals}

Edición electrónica

URL: http://journals.openedition.org/artelogie/2201

DOI: 10.4000/artelogie.2201

ISSN: 2115-6395

Editor

Association ESCAL

Referencia electrónica

Miriam Oesterreich, "The Display of the 'Indigenous' - Collecting and Exhibiting 'Indigenous' Artifacts

in Mexico, 1920-1940», Artelogie [En ligne], 12 | 2018, mis en ligne le 07 septembre 2018, consulté le

10 décembre 2020. URL : http://journals.openedition.org/artelogie/2201 ; DOI : https://doi.org/

10.4000/artelogie.2201

Este documento fue generado automáticamente el 10 décembre 2020.

Association ESCAL 
The Display of the 'Indigenous' Collecting and Exhibiting 'Indigenous' Artifacts in Mexico, 1920-1940

Miriam Oesterreich

In 1940 the Mexican artist Frida Kahlo poses in front of shelves with all kinds of trinkets in her house casa azul, Coyoacán, Mexico City (fig. 1). 


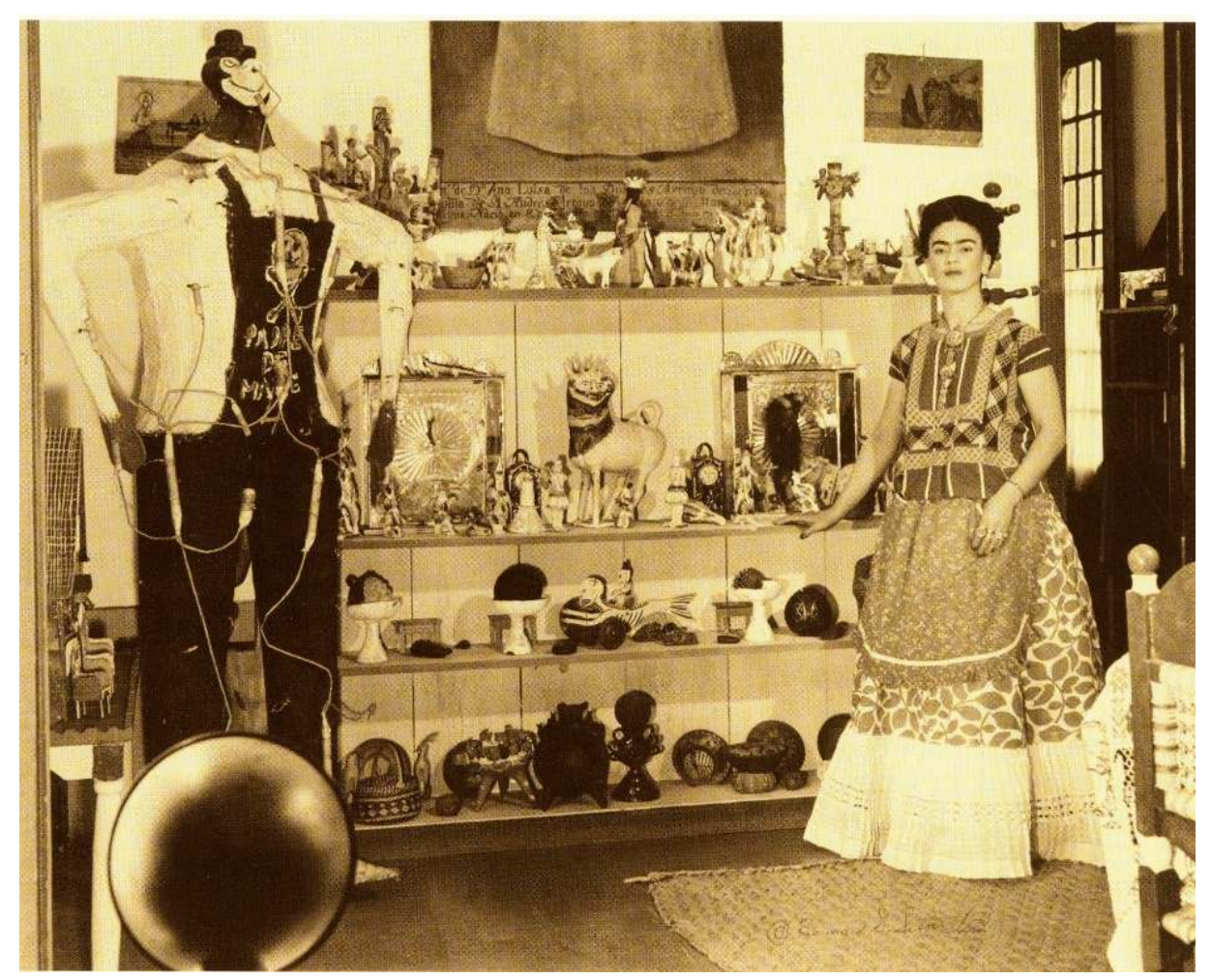

Fig. 1: Frida Kahlo in casa azul, ca. 1940, photographer: Bernard G. Silberstein. (DEXTER, Emma; Barson, Tanya, eds. (2005), Frida Kahlo, exh.cat. Tate Modern London, London/Munich, 15.)

2 At this point in time, Kahlo was famous at home and abroad as the wife of Diego Rivera, as a fashion icon, and as a painter with a solo exhibition two years before in the influential New York gallery Julien Levy - albeit far less prominent than her husband, who was prone to becoming entangled in scandals and, above all in the United States, revered as a virtuous artist. She is wearing the folkloristic costume of the Tehuana women. To begin however, I would like to focus on the objects so conspicuously presented on the shelves.

3 Striking in its presence is a judas de cartón, a Judas figure made of papier-mâché that is traditionally burnt on Easter Saturday in Mexico. Diego Rivera was a passionate collector of these papier-mâché figures and the one photographed here still has the fuse cords attached. ${ }^{1}$ It is known that Kahlo's house was also home to several Judas figures, for example next to the fireplace (fig. 2). 


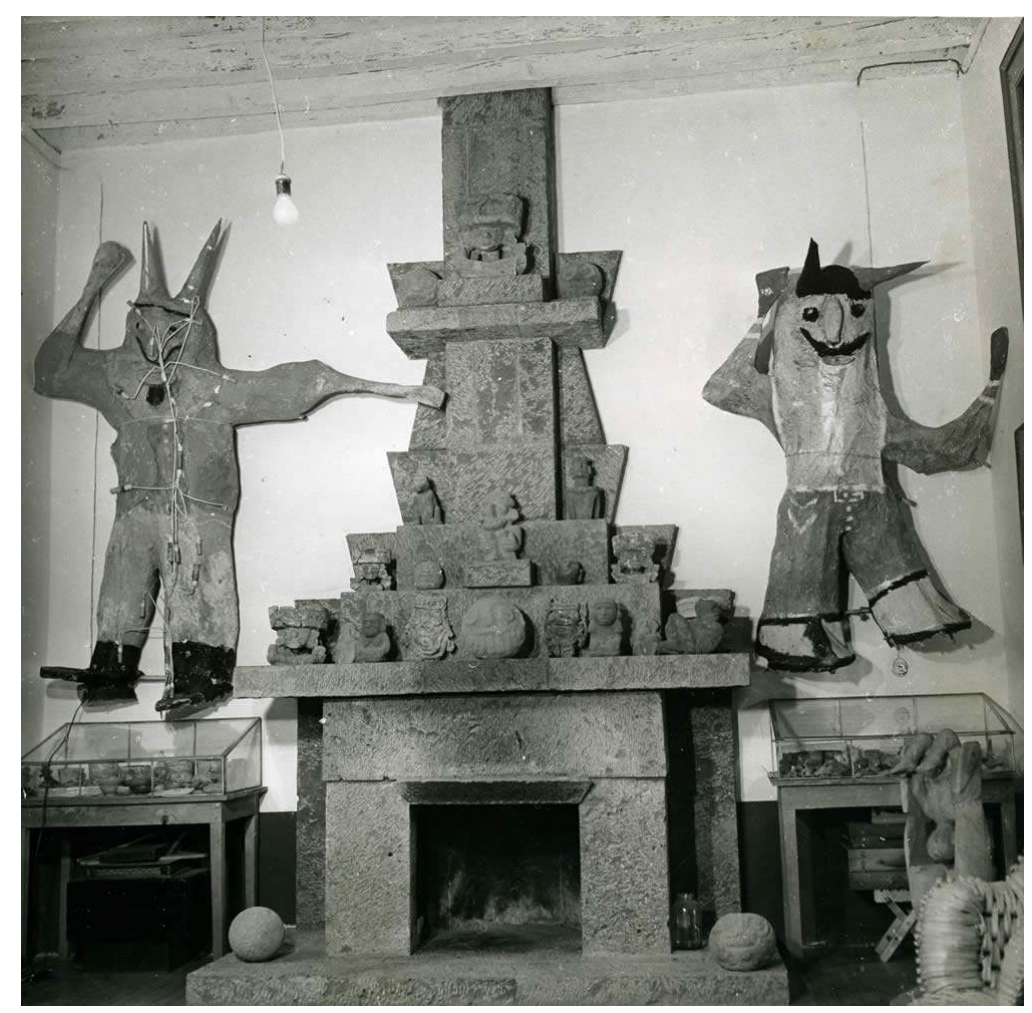

Fig. 2: Judas de cartón figures next to the fireplace in the casa azul, Museo Frida Kahlo, Mexico City. (source: http://www.museofridakahlo.org.mx/esp/1/el-museo/la-casa/la-casa-azul\#)

Retablos are on the wall, miniature Catholic votive pictures, mostly made by anonymous painters on metal or wood panels to be hung in churches as a symbol of gratitude to a saint for a received act of saving, healing or recovery. The donator tells the painter the story of the miracle and the painter depicts this in a picture. Indigenous ceramics and toys traditionally made in Indian communities as well as small Catholic home altars are also on the shelves. Kahlo is standing on a petate, a mat of woven palm leaves, traditionally used in Central America and Mexico as a sleeping mat, here though obviously serving as a kind of rug. ${ }^{2}$ Kahlo is posing for the American photographer Bernard Silberstein. Standing on the right from the viewer's perspective, she makes room for the presentation of the handicrafts. But given that she is even in the photo and her presence first highlights the objects allows us to see them as part of an enhanced portrait, and so as objects which are closely related to Kahlo's self-understanding as an artist.

This paper takes up a dual concern: to look at the role of regional handicrafts in the postrevolutionary process of constructing a unified, homogenous, and indigenous-oriented national identity in Mexico, and secondly to problematize the relationship between the positive cultural reevaluation of the rural and indigenous with modernist art practices. Here, the public and private collecting and displaying of pre-Hispanic and folkloristic artefacts are to be read as a form of indigenous-modernist art practice. This raises the question of the accuracy of defining binary categories like 'public' and 'private', 'regional' and 'indigenous', and 'traditional' and 'modern'. The goal is to critically review the appropriation practices and authentication strategies of modernist artists involved in a nationalist discourse. 


\section{Arte popular and Modernism in Mexico}

6 From the 1920s on, following the Mexican Revolution through to a process of national unification and international positioning, Mexico was dominated by an indigenist discourse. During the search for national Mexican identity, to be established following the end of the active revolutionary years, the indigenous emerged as a mark of difference and unique characteristic, both politically and socially. In effect, this meant that elite and intellectual circles ideologically reevaluated the indigenous positively, emphasizing it as being characteristically Mexican. But because this search for national unity was a concern of the mestizo elites, the mestizo, also conceived biologically as a mixture of the European and indigenous, was taken to be particularly modern and pioneering for the nation's future. As the pure, original, and 'authentic', the indigenous was always the starting point for modernization, but also excluded from it. ${ }^{3}$ However, entanglements with European traditions, North American modernity, and Latin American artistic movements create a notion of the 'modern Mexican nation' that is simultaneously (and at first sight, paradoxically) restricted to national borders and extremely cosmopolitan. The emphasis of the specifically Mexican is thus from the very beginning embedded into a cosmopolitan network of intellectuals and artists; and especially between Mexico City and New York there exists an increasingly intensive exchange based on displaying the 'indigenous' as the 'Mexican'.

7 Indigenism went hand in hand with a broad cultural revaluation of handicrafts, known as arte popular. ${ }^{4}$ Even though a romanticized image of the indigenous had already emerged in the nineteenth century, with artists employing - in a heroic and mythological exaggeration - picturesque motifs to represent Aztec or other indigenous groups, this form of exaggeration remains tied to the aesthetic canon of academic art history. This pertained exclusively to extinct high civilizations, while the contemporary indigenous and their artistic and handicraft practices were taken to be mere monuments to a lost cultural grandeur. Before the Revolution, Mexico's middle and upper classes, along with foreign visitors, had seen handicrafts as an embarrassing indictment of the purported backwardness of the indigenous (LÓPEZ, 2010: 2). The contrary view was held in postrevolutionary Mexico, so that the "living [contemporary] indigenous heritage" was now "a vital component, even the foundation [and a proud symbol] of Mexico's authentic national identity" (LÓPEZ, 2010: 7). Nevertheless, not all indigenous handicrafts were ascribed the capacity to function as a force unifying the national, nor to create a specific form of modernity; on the contrary, debates raged as to which aspects of the popular arts needed to be focused on and which did not deserve public attention due to their 'backwardness' (LÓPEZ, 2010: 30). In this context, indigenous cultures already popularized in the nineteenth century and the nationalized landscapes surrounding Mexico City came to be national symbols, witnessed by the diverse visual inventions of the tehuana or the china poblana, the charro or the mariachi. ${ }^{5}$

8 Handicrafts were mostly produced and sold in indigenous communities and traditionally in rural areas, and with the migration of the indigenous to the cities looking for work also there on a significant scale. The Mexican government was decisively involved: it propagated regional folklore and indigenous handicrafts as symbols of national unity. An ideological homogeneity was constructed out of very different regional cultures and very diverse handicraft techniques and aesthetic traditions. "[P]etate dolls, jícaras [containers 
made from the fruit of the calabash tree], clay toys and colorful sarapes [blanket-like shawls]" gave the Mexicans, claimed the writer and culture critic Salvador Novo in 1932, "an exalted racial sense and a consciousness of nationality previously lacking" (NOVO, 1932: 35).

9 All of the objects shown were familiar from contemporary modernist journals and magazines, which were not only read in artistic circles but in large part editorially planned and designed by them. Since 1925 Mexican Folkways was published bilingually and in close cooperation between Mexican and North American authors. The editor was the North American Frances Toor, who had lived for decades in Mexico and herself was part of the bohemian circle of the indigenist artists (CANO, 2014; DE LA ROSA, 2014: 82). The magazine covered subjects like Mexican folklore, archaeology, ethnography, and handicrafts, as well as presenting and discussing the avant-gardist works of modernist artists. ${ }^{6}$ Looking back in 1932, Frances Toor summarized the intention behind the magazine and drew a causal connection between handicrafts of indigenous origin and modernist art production:

"Mexican Folkways has played an important role in the formation of the new Mexican attitude toward the Indian by making known his customs and art; and for the same reason the magazine has had an important influence on the modern art movement." (TOOR, 1932: 205)

A photograph by Tina Modotti in an issue of Mexican Folkways from 1926 shows "A Charlie Chaplin Piñata", 8 a larger-than-life papier-mâché figure. Diego Rivera had published an essay in 1925 in the same magazine on the retablos, entitled "The True and only Pictoric Expression of the Mexican People" (RIVERA, 1925: 7-9). The retablos, he claims, bring to light the indigenous soul, fully unmediated and directly: "These paintings are the expression of the deepest spirit in the people, achieved plastically with technique that is pure, intense, sharp, sometimes infantile, always of simple, and therefore infinite, craftsmanship" (RIVERA, 1925: 8).

11 Figures and toys closely resembling the miniatures were featured in the magazine Forma. Revista de artes plasticas. Pintura-grabado-escultura-arquitectura-expresiones populares, which was published between 1926 and 1928 and also much read in the modernist circles: ${ }^{9} \mathrm{a}$ rubric called El sentimiento estético de los juguetes mexicanos regularly presented colored drawings of traditional toys on a double-page spread (fig. 3). ${ }^{10}$ 


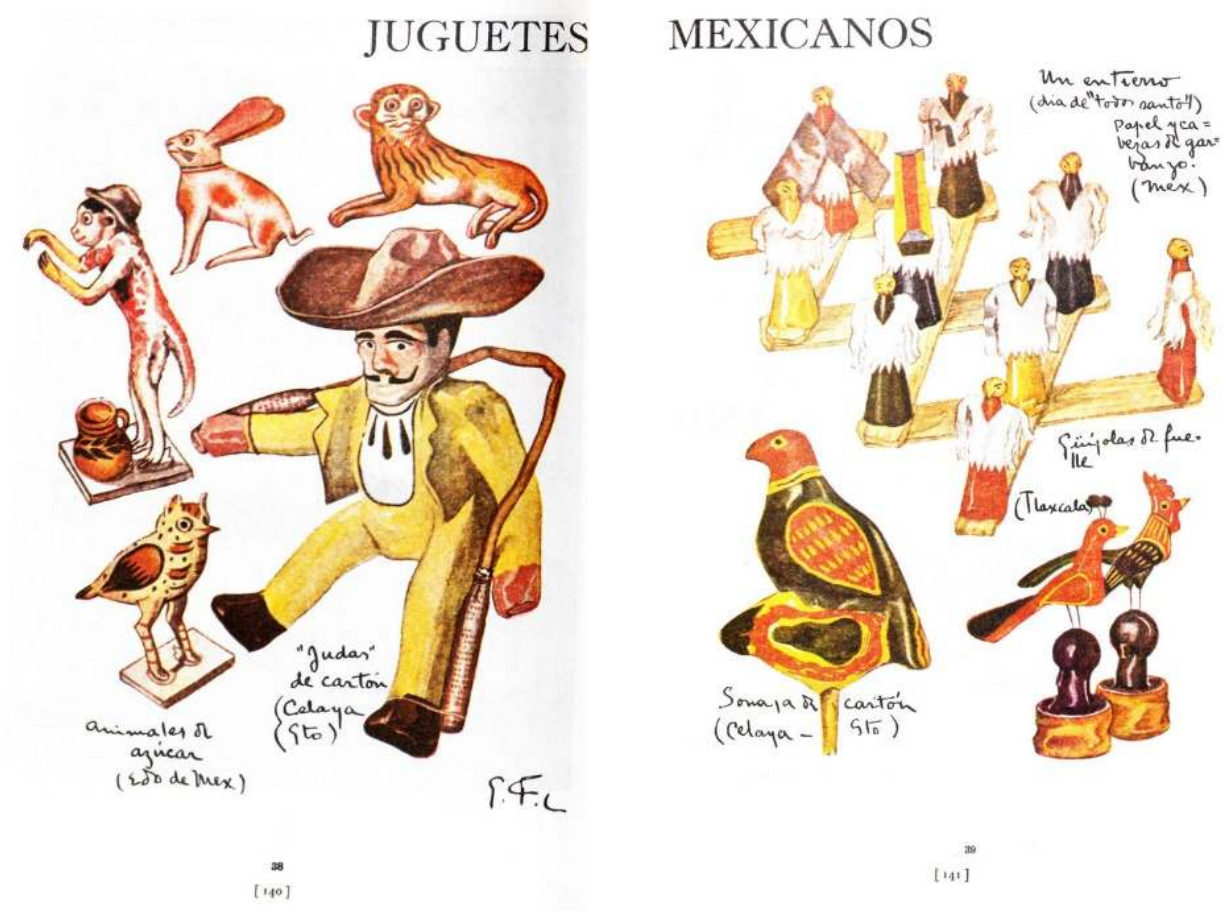

Fig. 3: Juguetes Mexicanos in Forma. Revista de artes plásticas, no. 3 (Mexico 1927), 140-141.

Handicraft figures are here elevated to the status of artworks through the presentation on white paper without a background and the manner of their depiction, but at the same time they are - like 'genuine' works of art - decontextualized. Whereas ethnographic photographs would place them in the context of their production, selling, or use, here they are treated as single pieces, the sole focus their aesthetic form, which is best highlighted when set against a pure white background. And while the traditional source of the toys is added in handwriting, enhancing the 'authenticity' of the objects as being 'original', there is however no need to specify this very origin.

\section{The Display of arte popular: Teaching mexicanidad to Mexicans}

13 The Centenario celebrations in 1921 to mark one hundred years of independence from Spain can be seen as the beginning of the public exhibition of handicrafts and their positive reevaluation into a national allegory. The curatorial practices reaching a broad public in Mexico right after the Mexican Revolution were the first monumental and official attempts to visualize and spectacularize an intention, namely to create and forge a modern national identity via the inclusion and appropriation of a glorified and nationalized indigenous culture (LÓPEZ, 2006).

That the first Exposición de Arte Popular was commissioned by the new post-revolutionary government of the now 'institutionalized revolution' and then opened personally by President Álvaro Obregon, indicates its relevance in the nationalist discourse, which elevated cultural activities to the status of government work. ${ }^{11}$ After the planned industrial fair had to be cancelled, the modernist artists Roberto Montenegro, Gerardo Murillo (known as Dr. Atl), and Jorge Enciso came up with the bold project to exhibit 
'traditional' handicrafts from the whole of the nation as works of art. All of them had spent artistically inspiring years in Europe before coming back to Mexico, Montenegro and Enciso after the end of the revolution in 1921, just before their joint project for the centennial. With their proposal accepted, the originally planned emphasis on industry was replaced by the popular, the handicraft items presented and understood as an expression of the indigenous. The exhibition became such an important part of the celebrations that it "redirected the centennial away from a celebration of technological modernity, toward an ethnicized view of Mexican nationality" (LÓPEZ, 2010: 76).

Folkloristic objects from the whole national territory were shown together for the first time in this exhibition, a symbolical incorporation of all regions. ${ }^{12}$ Held in a building in the center of Mexico City, visitors were welcomed by folksingers and Yucatecan dancers, and could consume snacks of fresh tamales, atole, and chocolate served in folkloristic decorated booths. Two floors of galleries then presented handicrafts arranged by category: textiles, lacquer, ceramics, toys, etc. The rooms were crowded: textiles hung from the walls and shelves, while artesanía objects were stacked on the shelves and tables (LÓPEZ, 2010: 82) (fig. 4).

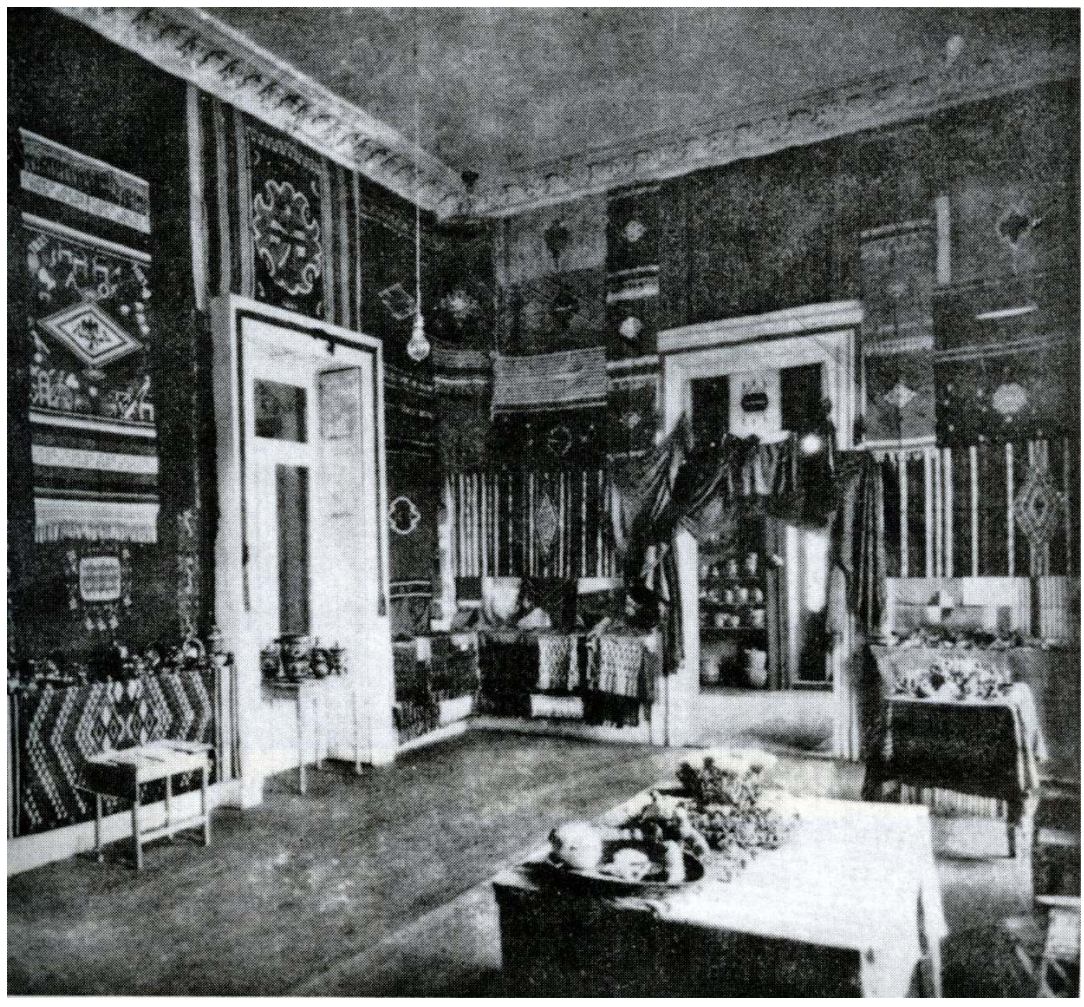

Fig. 4: Gallery view of the 1921 Centennial Exhibition of Popular Art, photo published in: TOOR, Frances (1939), Mexican Popular Arts, Mexico City.

Despite the aspirations of the curators to exhibit objects of art, the installation design tended more towards a popular reception of anonymously produced handicrafts. The organizers created the impression of indigenous or popular markets through the sheer number and constant repetition of forms (MONTGOMERY, 2014: 237). The textiles in particular, completely covering the walls in some rooms, made it impossible to view and reflect on them as individual objects. Neither display cases nor information labels or texts concerning the artists were used. Torn out of their original context, transferred and exhibited in a metropolitan museum, the normal manner of using these objects was not 
replaced by a museum presentation, but by a setting analogous with commercial display of objects up for sale. Augmented with the performative elements of the dancers, the consuming of food in the exhibition, and the stands selling popular items resembling those on show, the impression evoked is that of a giant spectacle, recalling more the practices employed at world trade fairs to generate broad public appeal than an exhibition in an art museum. ${ }^{13}$ While the vernissage could only be attended with an invitation, the exhibitions were open to all and entry was free. The exhibition proved extremely popular and attracted the interest of broad sections of society as well as foreign visitors. Exhibiting crockery and decorative objects on shelves and tables, cabinets or chests of drawers evoked a sense of inclusion of the objects in the functional settings of private households (VELÁZQUEZ, 2010: 65-66). The presentation can thus be read as inducing the middle-classes to integrate artesanía into their own living situation as decorative objects of everyday use. ${ }^{14}$ Some objects, above all toys, were positioned on the floor and thus imitated a direct presence, as if one were entering a household setting and children were really playing on the floor.

Dr. Atl, who put together an exhibition catalogue that was an encyclopedic two-volume work (Las artes populares en México, 1922), ${ }^{15}$ transferred the exhibition concept to the medium of the book, presenting handicrafts as a decontextualized aesthetic phenomenon. He specifically takes up the museological-scientific tradition, since the eighteenth century most prominent in natural science atlases, whereby similar structures are shown in a synoptic overview of the multiple variations of a single form. As a result, he positions the objects in a scientific tradition, i.e. as objectively analyzable exhibits without any subjective, emotional connection or functional context, while simultaneously treating them as pure aesthetic works of art, which is the only expressive value they possess. A third aspect also comes into play: they appear as if ready for sale, similar to the later mail-order catalogue, lined up according to the similarities of their form on shelves. The 'Mexican' residing in the regional handicrafts is presented as 'affordable' for everyone.

The exhibition was thus the first that implemented and promoted the transfer of arte popular to the urban household. The colonial building was presumably the same as the residences of the economic elites, but the manner of the presentation made it clear that such objects were suitable for decorating any domestic setting and could be brought for this purpose.

In the exhibition catalogue Dr. Atl wrote:

"Hoy en día las gentes de buen gusto arreglan en sus casas un salón, una biblioteca, un saloncito de fumar 'al estilo de la Exposición'. Aquellas personas que no pueden darse el lujo de decorar toda una pieza, se conforman con decorar un diván con un sarape de gusto por las cosas del país está hoy día muy generalizado en todas las clases sociales." (MURILLO, 1922: 22)

Rick López has succinctly described this process:

"As people learned in the exhibition to value handicrafts as art rather than as curiosities or ethnographic artifacts, the middle and upper classes started to buy traditional crafts themselves in order to decorate their homes with it - so, the commercialization directly accompanied the process of aesthetic revaluation and musealization of craft objects. While wealthy families decorated whole houses like miniature exhibitions, people of modest economic means owned just one or two items, proudly shown in a special corner or a glass-front cabinet, thus also imitating museum displays at home." (LÓPEZ, 2010: 85-86) 
21 artefacts from the pre-Hispanic cultures on a large scale; almost every artist had such objects on display in their studios and living rooms, and at the time this was a form of self-definition as being eminently modern in an intellectual sense (BRAUN, 1993). Diego Rivera for instance cooperated with the architect Juan O'Gorman to build the Anahuacalli, which was to serve as a home and exhibition space for his collection of pre-Columbian artefacts while simultaneously being a living quarters and studio - collecting and exhibiting pre-Hispanic artefacts and his own work producing 'modern' art were conceived as two sides of the same artistic practice, whereby the private became public, and the public - in the form of the 'national heritage' - moved into the private domicile.

Collecting and studying pre-Hispanic and folkloristic artefacts was by no means an interest limited to Mexican artists; it was tied into the transnational artist networks which established the international reputation of Mexican handicraft as an important element in the avant-garde's engagement with 'primitive' aesthetics. Wolfgang Paalen, who lived in Mexico and put together the Exposición Internacional del Surrealismo there in 1940, contributed ethnographic pieces from his own collection (GARZA USABIAGA, 2016: 41; GARZA USABIAGA, 2012). While teaching at Black Mountain College in North Carolina, an engagement that started in 1933, Anni and Josef Albers journeyed together to Mexico and South America on no fewer than fourteen occasions, moving Josef Albers to claim: "Mexico is truly the promised land of abstract art, which here is thousands of years old" (Josef Albers 1936, quoted in BLUME, 2015: 263). Both photographed enthusiastically in Mexico, and Anni Albers adopted - more or less abstracted - the forms tried out here into her handwoven wall-hangings and abstract paintings and graphics (HINKSON, 2017; REYNOLDS-KAYE, 2017; DANILOVITZ, 2007). The couple compiled a large collection of preHispanic miniatures, later published in a photo book by Anni Albers in 1970. ${ }^{16}$ Henry Moore also studied pre-Hispanic artefacts and they were one of the influences behind his own aesthetics of form. Like the Surrealists André Breton and Paul Éluard, he collected ancient Mexican sculpture (see ADES, 2015; BRAUN, 1989). And the architect Frank Lloyd Wright, to conclude this overview, was one of the best-known proponents of the Mayan Revival style, which adopted and varied pre-Hispanic architectural elements for modern buildings (see INGLE, 1984).

23 As Victor González writes with reference to the Exposición, the "'museización' de las [...] artes populares" (GONZÁLEZ, 2015: 60) decontextualized the indigenous and popular objects of everyday use and ennobled them into objects of aesthetic perception, much in the same way as the visibility of the artesanía in the museum had initiated a domestic appropriation across broad sections of society, which though was altered again by the avant-garde who showed off their collections in a private space, accessible but for a restricted public. The objects in artist households and studios thus had an ambivalent position within the economy of private and public visibility; the deliberate showing of the private can be interpreted as an avant-garde gesture, a key part of the respective artist's public self-staging.

Roberto Montenegro assumes a key role in this semantic field, for he, a modernist artist and a collector of popular art both privately and professionally, 'musealizes' his private collection. On the one hand, he provides many public exhibitions with a large number of works from his private collection; on the other hand, as the first director of the newly founded Museo de Artes Populares (1934), a museum catering for a broad public within the Palacio de Bellas Artes and hence spatially expansive enough to ennoble the objects, he 
created a location to present and fashion his collection. The boundary between private and public space, the respectively distinctive visibility of art and popular culture, and the difference between private home and museum all become porous in this process.

\section{The Display of arte popular: Teaching mexicanidad to Foreigners}

Like many other artists and intellectuals of his time - and often after extended periods of a training in modernist aesthetics in Europe -, Roberto Montenegro had been sent by the Public Education Ministry to the Mexican countryside to collect popular art pieces and to study the costumes, crafts, and customs of the rural population. While gathering these immense stores of popular handicrafts, which were then often shown in exhibitions like the aforementioned show, the intellectuals 'discovered' their own country, much in the same way as a tourist, and so made it accessible and consumable for tourism in the first place - and the 'authentic' traditional objects were transformed into souvenirs as their prominence and recognition grew (see GARCÍA CANCLINI, 1993).

In this regard, the early staging of the indigenous as representing the national and the traditional as epitomizing the modern, like the Exhibition of Popular Arts in 1921, can be interpreted as manifestations of the national for Mexicans themselves, as an aesthetic strategy to unify diverse social strata into a single national identity by means of cultural politics and as a touristic development of the provinces; in contrast, later displays of 'the Mexican', mainly in the US, addressed a non-Mexican clientele eager to tour the picturesque continent in the south, so that 'the Mexican' gradually turned into a commodity for tourist consumption. Harper Montgomery has argued that attributing Indians with an innate impulse to work and a deep affinity to the materials they worked with was ultimately used to promote the migration of Mexican laborers to the United States (MONTGOMERY, 2014: 236). The publisher Frances Toor, actively mediating culturally between the United States and Mexico in many segments and promoting the nationalization of Mexican folklore with her magazine Mexican Folkways, brought out a Motorist Guide to Mexico in 1938, thus also contributing to the touristic 'development' of the country by US visitors. ${ }^{17}$

As early as 1932 Anita Brenner had published her guidebook Your Mexican Holiday. A Modern Guide, which was not only illustrated in a 'modernist' style by Carlos Mérida and José Garduño, but proclaimed modernity in its title. That Toor's guide explicitly addressed motorists shows how contrastive the difference between technological progress, serving and used by mobile tourists, and a stationary folklore, far removed from technology and the domain of the 'locals', was perceived to be - similar to the posters appearing in New York in 1940 that advertised tourism to Mexico with the same hierarchical contrast: underneath the image of a Mexican woman, eroticized through her pose in 'pin-up' style, wearing a stereotyped costume and 'sombrero', and holding a horse by rope, comes the persuasive appeal: "Travel to 'air-conditioned' Mexico in airconditioned Pullman comfort." (fig. 5) 


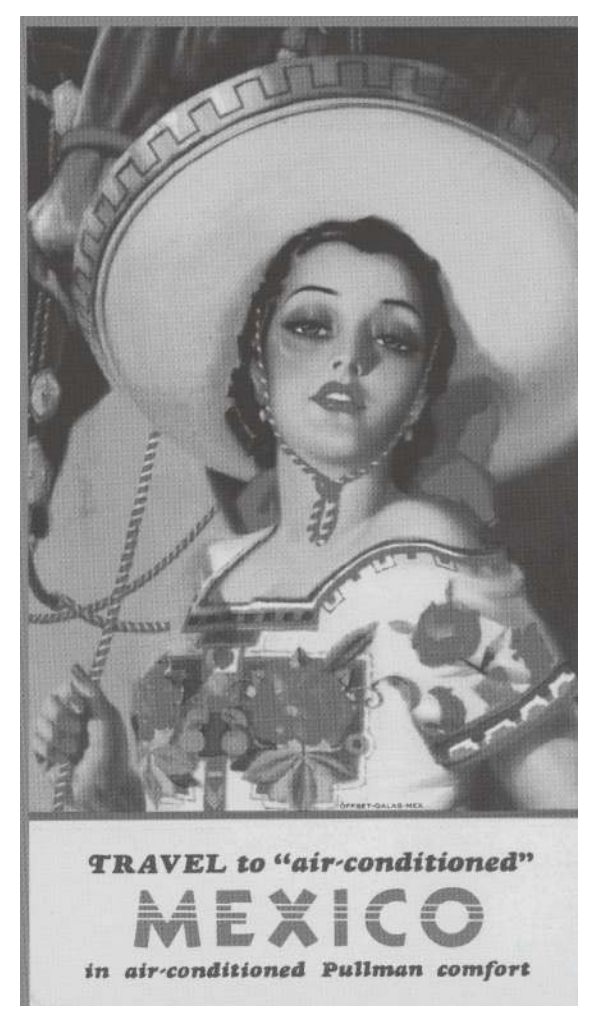

Fig. 5: Advertising poster in New York, 1940, Queens Museum of Art Archive. (Source: SCHMELZ, Itala, ed. (2012), Luis Márquez en el mundo de mañana. La identidad mexicana y la Feria Mundial de Nueva York, 1939-40, exh. cat. Queens Museum of Art, New York, Mexico City, 73)

The circle of artists propagating the indigenous as a picturesque element of modernist aesthetics thus also served as mediators between the two poles of tourist appropriation, both creating and bringing to attention touristic destinations as well as travelling and consuming themselves. In this sense, the 'display of the Mexican' can be understood as an aesthetic practice directed outwards that operated within a discourse on cultural appropriation geared to a primacy of the 'national'. As the public discourse on Mexican artes populares was dominated by modernist artists and intellectuals who presented the objects as part of their own modernist world, it was "somehow able to enlist Mexico into symbolizing the location of tradition and good taste, while the United States came to symbolize modernity and kitsch" (MONTGOMERY, 2014: 233). The balancing out of the various attributions to all those involved in the indigenism process is an expression of complex transregional exchange relationships, while also raising the question as to who has the position of interpretational sovereignty within this indigenist discourse, a question inherently ambivalent and obviously complex.

In 1938 the Museo local de artes e industrias populares was founded in Pátzcuaro, a region experiencing a tourist boom, and in 1940 the First Inter-American Conference on Indian Life was held there (GARCÍA CANCLINI, 1993: 44). As he was commissioned to curate the large-scale exhibition Twenty Centuries of Mexican Art in the MoMA, New York, Roberto Montenegro had already gained an international reputation: in 1922 he had designed the Mexican pavilion at the Centenario de la Independencia de Brasil in Rio de Janeiro and thereafter planned and carried out numerous other exhibitions of Mexican handicrafts, some of them abroad as national representations. In New York Montenegro was commissioned to curate the section on arte popular. ${ }^{18}$ Initially planned for Paris but then relocated because of the war, the show filled the exhibition spaces of the MoMA and even 
took up the museum's outdoor area, where stands were built to sell Mexican handicrafts. ${ }^{19}$ The exhibition was conceived in cooperation with the Mexican government, in this case the Instituto de Antropología e Historia, and served the construction of national continuities by emphasizing seemingly particularly relevant historical moments over the last two millennia. The cultural mestizaje, the development of Mexican art, is parallelized to a constructed historical story of progress from archaic times through to the modern age, whereby the crucial factor is the very land on which these developments unfolded Mexico the nation.

The bilingual exhibition catalogue shows first of all a Regional Map of Mexico with "Sources of Folk Art", followed by a "Map of Pre-Spanish Culture" with an index of "archaic cultures". From here, the first three sections are celebrated as quasi-typological parallels of national modernism (fig. 6).

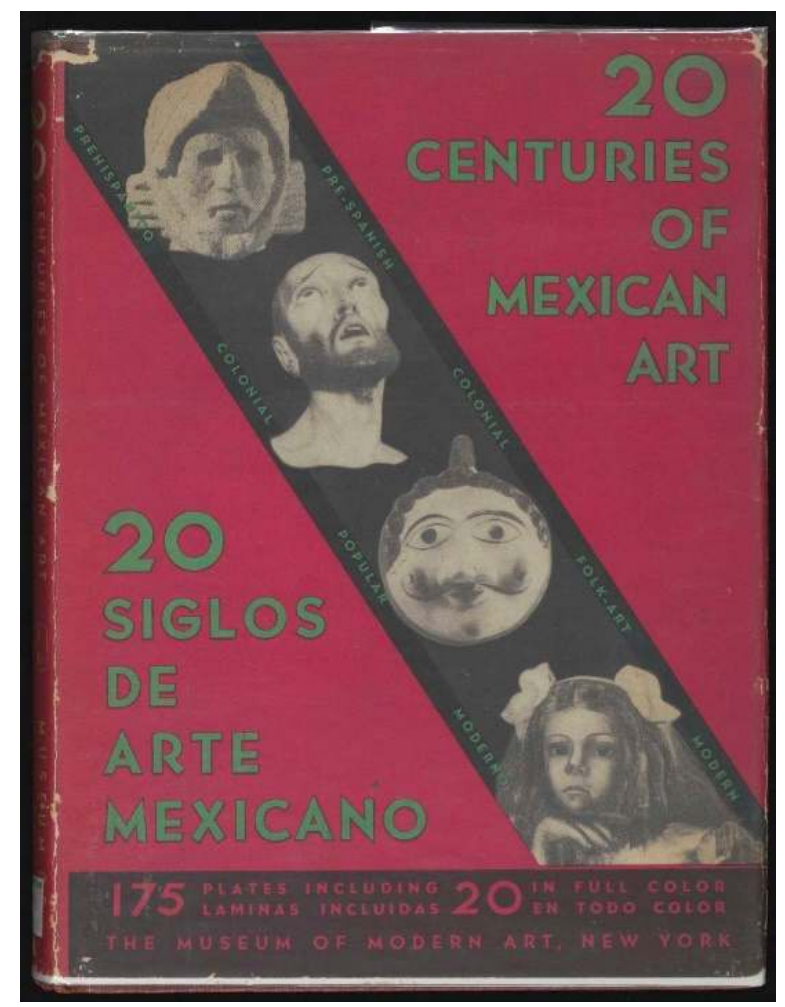

Fig. 6: Exhibition catalog cover for 20 Centuries of Mexican Art in the Museum of Modern Art, New York, 1940.

31 Some pre-Columbian sculptures are, so the claim, "surprising in their modernity. There are Tarascan statuettes that anticipate the essential and drastic simplicity of Brancusi, and Totonac masks that recall the poignant mortality which haunted Lehmbruck" (CASTRO LEAL, 1940: 15). In Mexican baroque, the indigenous artists in the service of the Spanish rulers tried "instinctively [to achieve] a simplification of form" (CASTRO LEAL, 1940: 15), while folk art links the two earlier art forms with modernity and thus has the place of an intermediary: "For it is in its folk art [...] that the two great traditions of Mexican culture, the Indian and the Spanish, are most completely harmonized in marvelously varied, abundant and esthetically satisfying forms" (FOREWORD of the Museum of Modern Art, 1940: 12).

In the introduction to the section, Montenegro states that the high quality of Mexican handicrafts stems from pre-Hispanic times, creating a seamless transition between 
history and the indigenous present. ${ }^{20}$ Similar to Rivera, he also describes traditional Mexican handicrafts as intuitive aesthetic expression, undistorted by artistic training or influences from other cultures - a stark contrast to how the artistas modernas were exhibited in the final section. Positioned at the symbolical end of the evolutionary development of art, they take the abstracting and intellectualizing step from the pure intuition for beautiful forms in the past and the assumed Indian present day through to a reflected reception and semanticization of such expression in art described as modern. The summary puts it as follows:

"[...] it should be noted that the objects which the Indian keeps for his own daily use are very different from the articles of commerce whose low quality turns a pure and exquisite art into tourist curios of no great importance. That is the reason why our folk art, in every period, has served as a true symbol of the artistic instincts of the Mexican people." (MONTENEGRO, 1940: 110)

In 1925 Diego Rivera had lambasted the commercialization and decorative appropriation of handicrafts by tourists and members of what he disparagingly labelled as the "bourgeoisie", seeing it as destroying the 'pure', 'authentic' and always 'intuitive' expressive force: ${ }^{21}$ the result was an "enormous and filthy river of pottery manufactured in neo-Barcelonese and sirio-Libanese styles, to the taste of provincial Yankees and Central Europeans, which river of stuff settles into the corners of musty bourgeois homes" RIVERA, 1925: 8).

Montenegro clearly exhibits retablos as a source of spiritual and aesthetic inspiration for modernist artists, capable of lending the work of these modern artists a particularly authentic and Mexican sheen, while at the same time disparaging the very same handicrafts because they can never be more than inspiration and elegant accessory:

"The story of the miracle as told by the donor is interpreted by the painter with primitive ingenuity and charm and deep religious faith. Ignoring the laws of perspective, he represents the characters, the place, and the event with a direct and naive simplicity, frequently achieving small masterpieces in color, composition, and dramatic feeling. Our great modern painters have found in these 'retablos' one of the authentic expressions of Mexican painting" (MONTENEGRO, 1940: 110, emphasis mine).

The exhibition softened the otherwise rigid distinction between private household and public museum (aside from the opportunity to purchase at the museum handicrafts for home) in how the functional objects were placed in a direct dialogue with classical genres, foremost painting and sculpture, but also in how objects were inserted into the museum context which were traditionally objects of everyday use in private contexts. Like the houses of Kahlo and Rivera, MoMA also presented a Judas figure in the foyer (fig. 7). 


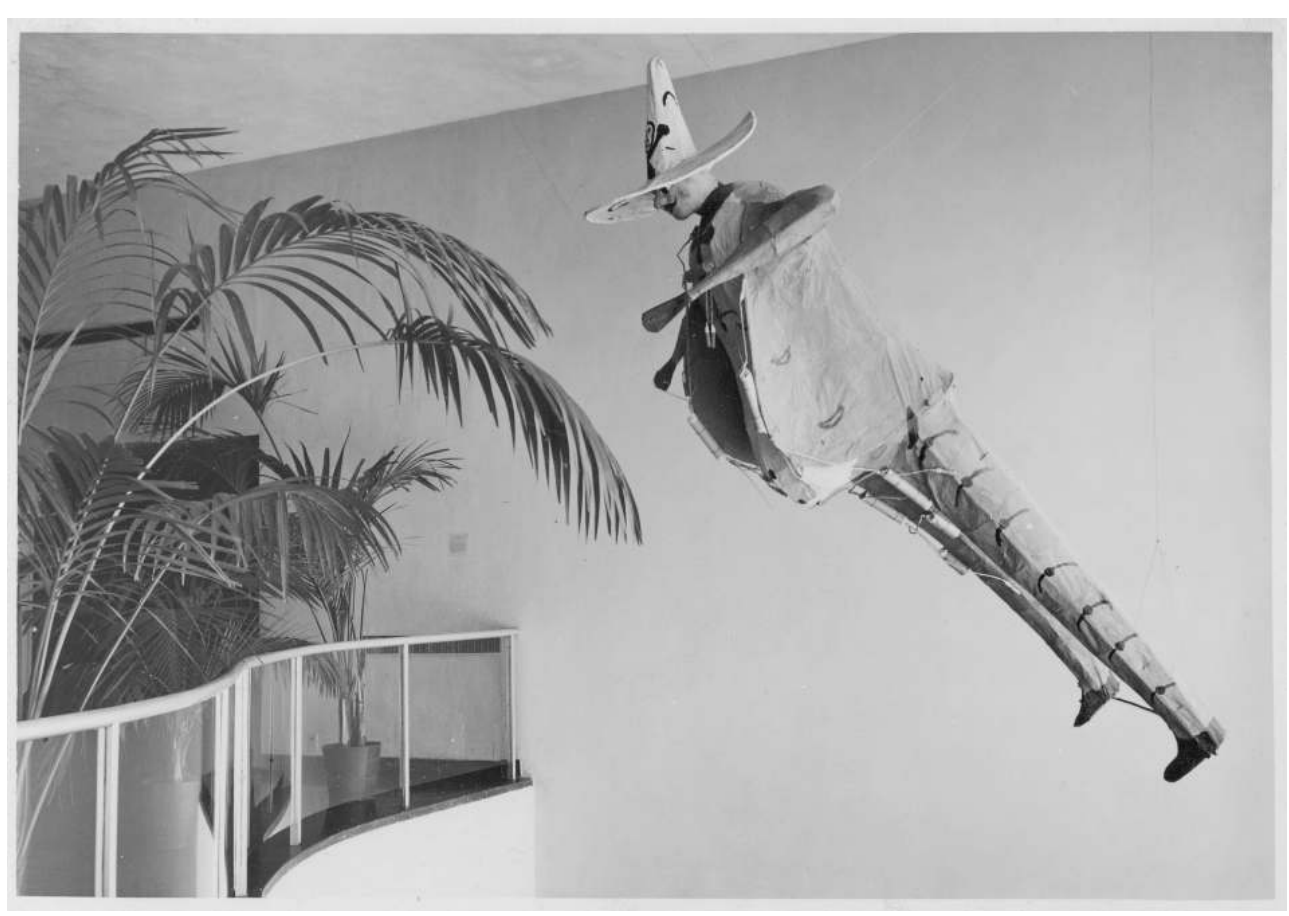

Fig. 7: Judas de carton in the foyer of MoMA, New York, exhibition view of Twenty Centuries of Mexican Art, 15 May 1940 - 30 September 1940. Photographic Archive. The Museum of Modern Art Archives, New York. IN106.8, (https://www.moma.org/calendar/exhibitions/2985/installation_images/13068).

Not represented in the exhibition was the period connoted with European, decadent influences and thus considered as not expressing 'Mexican' creativity:

"[... D]uring the turbulent period of Itúrbide, Santa Anna and Juárez, and the ensuing long regime of Díaz, the official art of Mexico seems bound to foreign tradition. But the creative talent of the nation was kept alive in its popular art [...]." (FOREWORD of the Museum of Modern Art, 1940: 11)

Another major event took place in New York in 1940 that featured a 'display of the Mexican': at the New York World's Fair, Mexico was presented under the motto of "Building the World of Tomorrow". Although one event is located in an art museum and aims to foster an appreciation of fine arts for an elitist public who is used to seeing and comparing artworks, and the other is part of a large popular presentation of the best or typical features of a nation within the context of many other national and US industrial presentations at a World's Fair - while in Europe the Second World War was raging -, several aspects bind the two events to each other. Firstly, both were held in New York, culturally and economically the center of the world at the time; secondly, both negotiated a conception of 'the Mexican' by directly juxtaposing the traditional and the modern, claiming a very special version of tradition and indigenous past as constitutive for a new vision of the modern Mexican nation.

The Mexican Pavilion at the 1939/40 World's Fair was situated in the so-called 'foreign nations section' rather at the periphery of the fair grounds. The overall design of the newly developed Flushing Meadows Park was a future-oriented architectural symbol for modernity, with Trylon and Perisphere futuristic architectural landmarks. A Ford advertisement brochure, accompanying the presence of the automobile company at the Fair, celebrates modern motors, progressive industry, and consumerism (FORD NEWS, 1939). The advertised women's outfits for a fair visit were explicitly modern and urban: "Any woman headed toward New York wants some town-wear that sets her up sartorially. 
[...] Therefore, please, no peasant hankies tied around heads!" (FORD NEWS, 1939: 83, emphasis mine). The advertising text strongly implies a tourism aspect: the fair was meant to be visited by tourists from outside the metropolis, people not used to overwhelming spectacles of modernity, and there is thus an overt attempt to 'educate' them as to what urban consumerism and cosmopolitanism means; in short, the country was invited to the city with the intention that those who visited bring back economic and industrial consumerism to the country. And it seems that this invitation to the provincial folk was not only addressed to the fair visitors but also to nations - they were to adopt the US model of the capitalization of civic life and bring the "American way of life" to their native countries. At first, this demonstrative celebration of modernity, capitalist growth, and technological progress differed from the interior presentation of the Mexican Pavilion. Here the visitor entered a space glorifying the indigenous and traditional way of life as still practiced in rural Mexican regions (fig. 8).

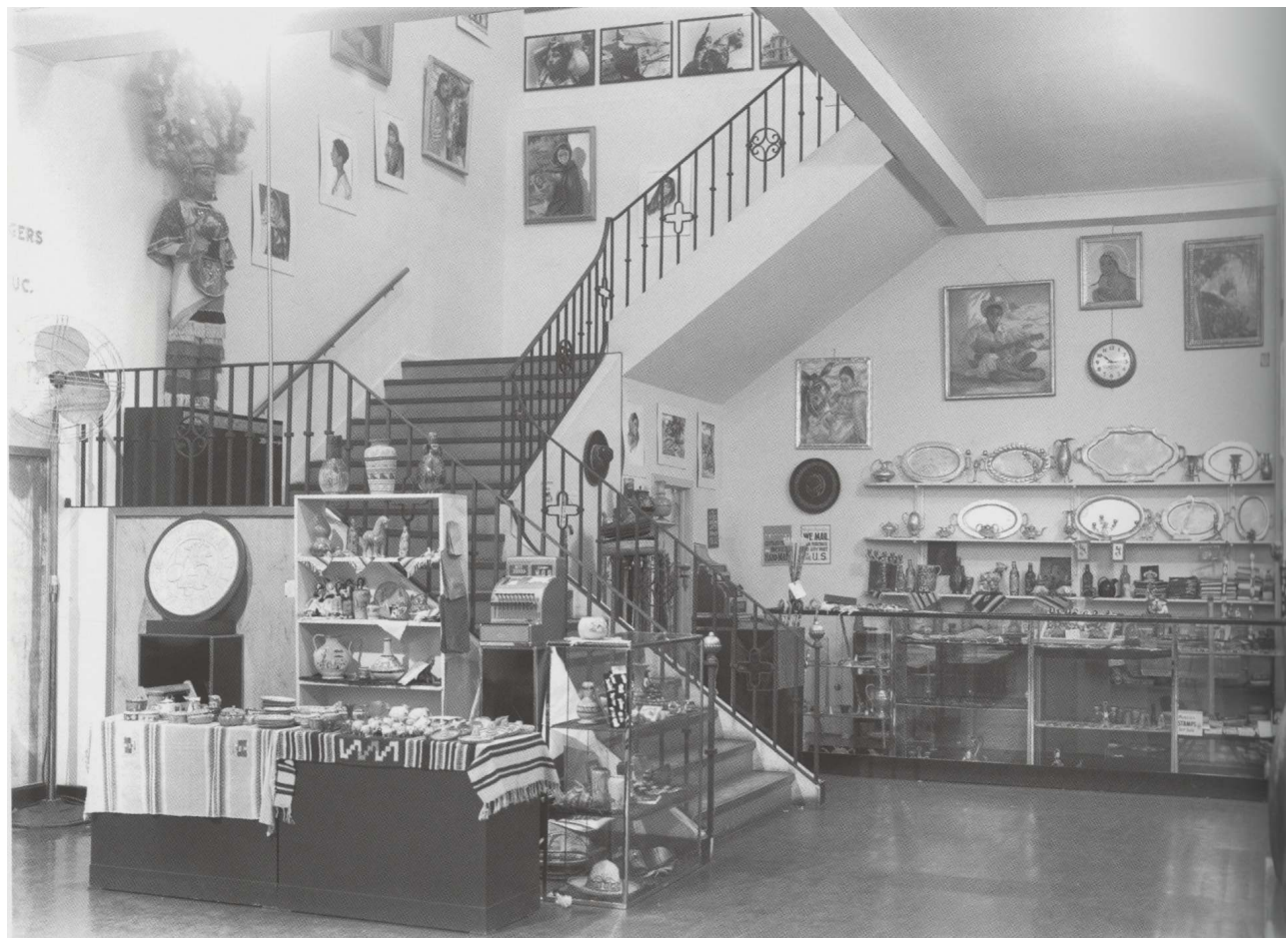

Fig. 8: Interior view of the Mexican Pavilion at the New York World's Fair, 1940, curated by Luis Márquez, photographer: Luis Márquez. (SCHMELZ, Itala, ed. (2012), Luis Márquez en el mundo de mañana. La identidad mexicana y la Feria Mundial de Nueva York, 1939-40, exh. cat. Queens Museum of Art, New York, Mexico City, 130)

The inside of the Pavilion featured a modernist exhibition design with display cases, the vast array of diverse ethnographic artefacts, paintings, photos, and crafted pieces arranged in special settings, including a montage of enlarged photographs or full-scale reproductions of pre-Hispanic archeological artefacts. The dominant themes were Mexican arts from pre-Columbian times to the contemporary era and tourism, which was based on President Lázaro Cárdenas's six-year development plan (SCHMELZ/PEÑALOZA, 2012: 16-17) (fig. 9). 


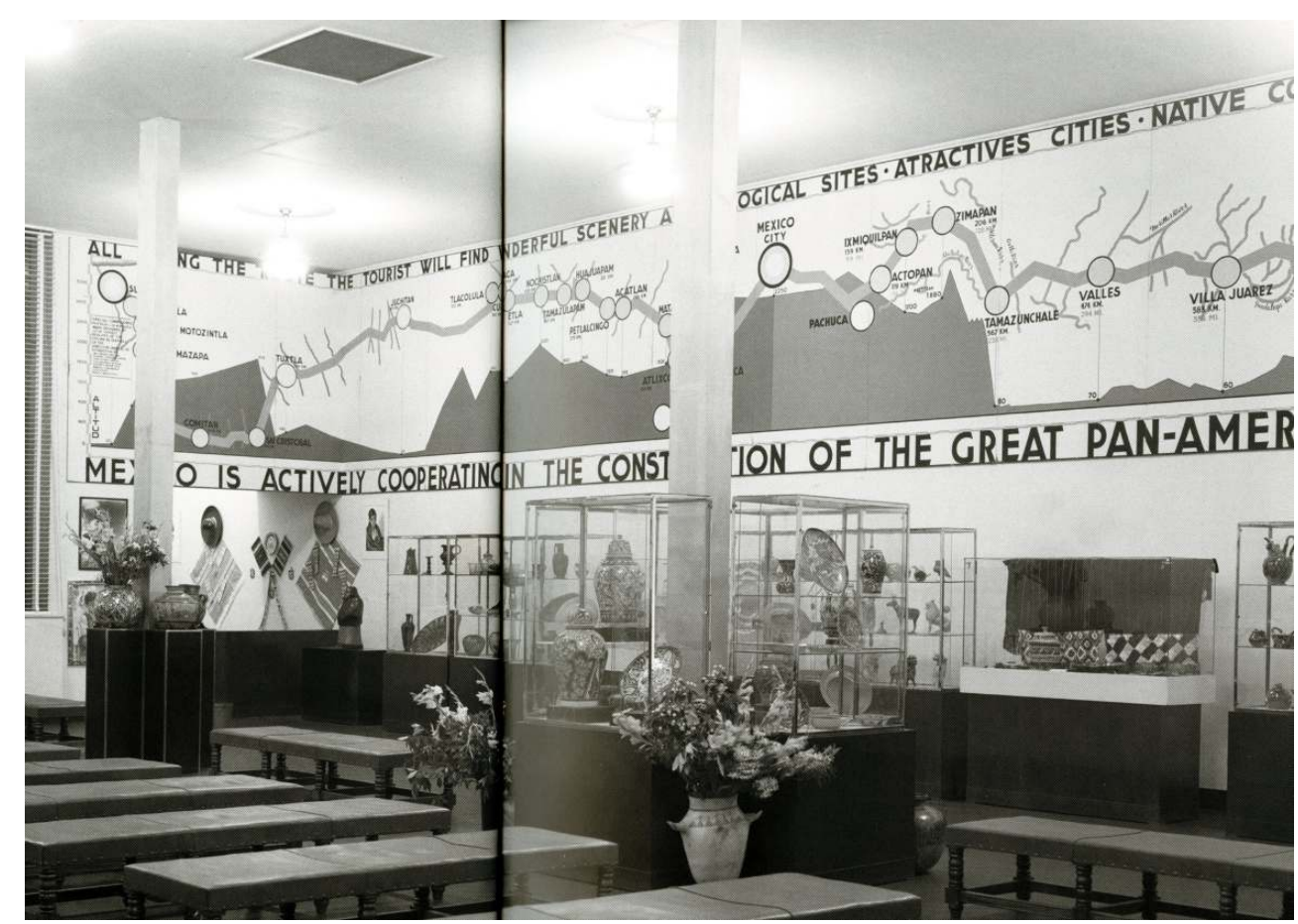

Fig. 9: Interior exhibition view of the Mexican pavilion at the New York World's Fair, 1940, curated by Luis Márquez, photographer: Luis Márquez. (SCHMELZ, Itala, ed. (2012), Luis Márquez en el mundo de mañana. La identidad mexicana y la Feria Mundial de Nueva York, 1939-40, exh. cat. Queens Museum of Art, New York, Mexico City, 20-21.)

Spectacularly, there were not only life-size copies of indigenous people in the exhibition but also local hostesses (and some male counterparts) in traditional costumes, posing for and with visitors and bringing to life the exhibits in daily shows of folkloristic dances. There was also a gift shop situated in the pavilion where visitors could buy reproductions of ancient Mexican artefacts and handicrafts, blurring any distinctions between cultural education, popular entertainment, and touristic consumerism.

41 Given that it is extremely unlikely that Mexico aimed to present the nation as backward and traditional, it seems rather probable that all was geared to creating a very specific form of modernity, one that drew on traditional and interlinked attributions like the authentic, indigenous, rural and unintellectual. But how was this arbitrary conception of modernity constructed and how did it work?

\section{The Private, the Public, and Tourism}

In the same year, 1940, Frida Kahlo is represented in the MoMA exhibition with her complex, symbolic panel painting Las Dos Fridas and poses for the photograph in her private domicile in front of her collection of Mexican handicrafts (fig. 10). 


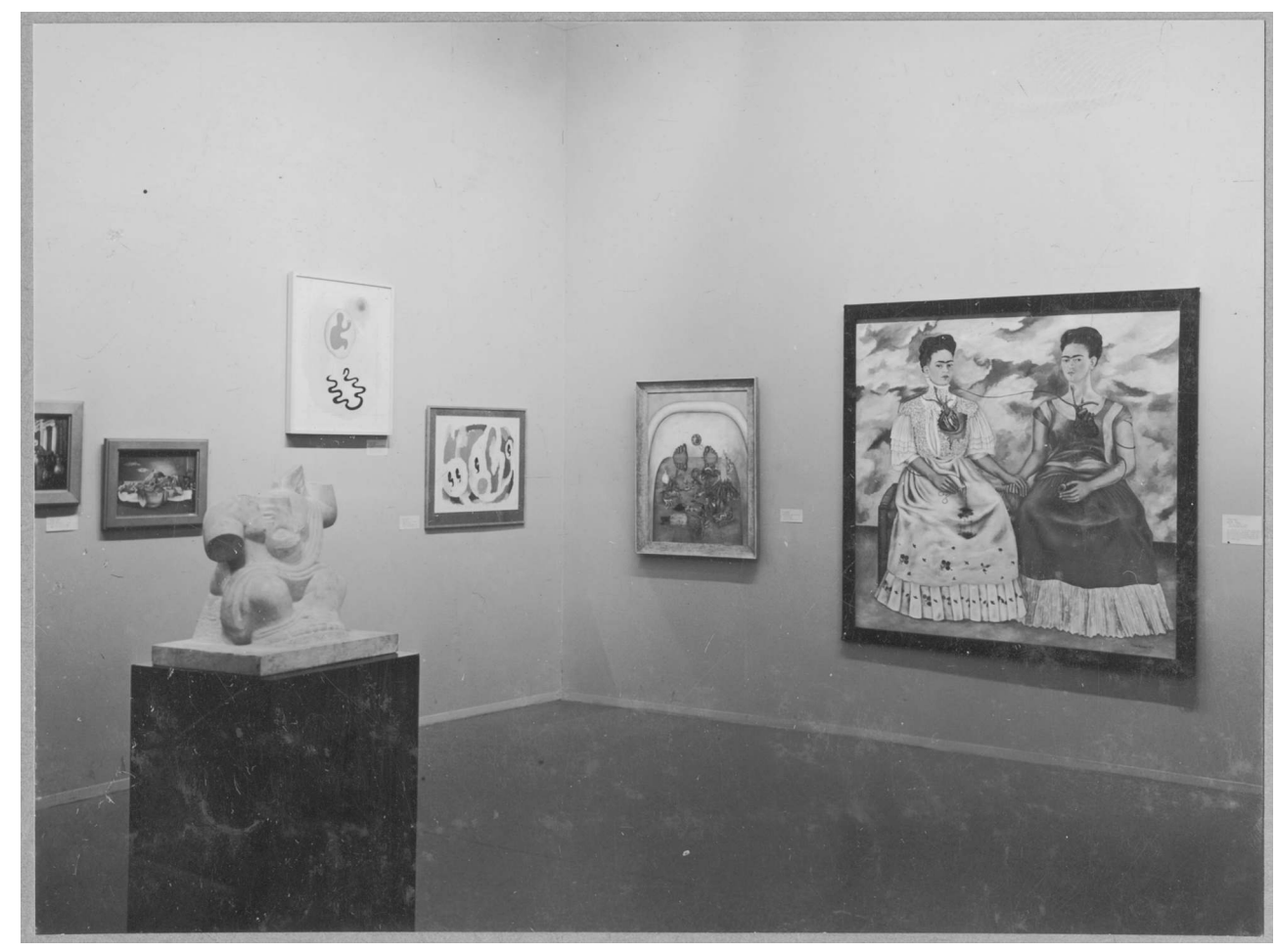

Fig. 10: Exhibition view from Twenty Centuries of Mexican Art, MoMA, New York, 1940.(https:// www.moma.org/calendar/exhibitions/2985/installation_images/13085?locale=en)

Given this constellation, the objects presented by Frida Kahlo are not necessarily to be understood as an appreciation of indigenous handicrafts as works of art, but rather as an enhancement of her own artistic status, achieved by showing the reference points for her own art, no longer 'intuitive' or 'naïve' but epitomizing a reflected aesthetic appropriation of a canon declared to be steeped in national tradition. This mode of aesthetic appropriation of de-contextualizing and then re-contextualizing a repertoire of forms, itself celebrated as a direct expression of 'primitive' - i.e. indigenous - creative power, is itself a primitivistic, indigenistic artistic practice. ${ }^{22}$ The collection and public/ semi-public exhibiting of pre-Hispanic and handicraft artefacts can itself be described as a modernist art practice.

This form of artistically generating a specific modernity through a re-semanticizing running contrary to the established conception of the time and class, creates a series of hierarchies, temporal, social, intellectual, and ethnic. What is specific Mexican in this situation, distinguishing it from primitivistic practices in Europe and North America, is how the artists clearly position themselves in the very same space as their reference objects. In the 1980s Johannes Fabian noted the cultural mechanisms at work that construct a distance in "time and space" between "anthropology and its object". ${ }^{23} \mathrm{In}$ Mexico, this aspect of spatial distance is relinquished in favor of a co-opting of the indigenous, declaring it to be a shared space (while ignoring other dimensions). It is the cultural occupation of the same geographic space and its sources of aesthetic inspiration by modernist artists that first makes the cultural nationalism of the so-called Mexican Renaissance possible, particularly in distinction from Western avant-garde tendencies which also experiment with aesthetic spirituality. In contrast, the contemporary indigenous is conceived as temporally distant, an image of pre-Hispanic 'heroes' from the 
high cultures of the rural regions envisioned, whereby however the current rural population is denied any active participation in societal processes (VELÁZQUEZ, 2010: 58).

I would therefore like to propose that the private/non-private collecting and exhibiting of pre-Hispanic artefacts and popular handicrafts can be interpreted as an artistic practice pursued by indigenism, and that it is precisely in this sense that drawing anachronistically on 'old' traditions is indeed capable of creating a specific artistic modernity.

The propagated 'authenticity' of the exhibited handicrafts is called into question when consideration is given to their use as tourist souvenirs. Another photograph of Kahlo posing in front of her collection exemplifies this (fig. 11): she is wearing the traditional wedding dress of Tehuana women, a lace veil revealing her face. Besides scores of ceramic pieces and small toy figures on the shelves, a large ceramic jug on the floor attracts the viewer's attention, the words "recuerdo de" and a place name - undecipherable associated with the souvenir.

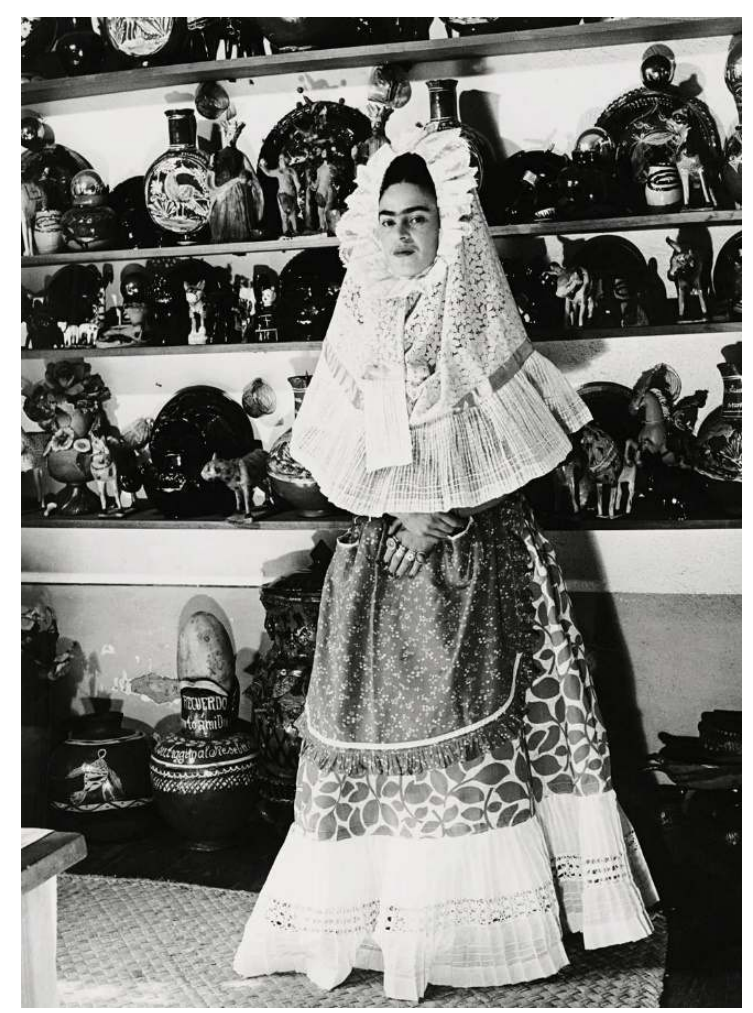

Fig. 11: Frida Kahlo in casa azul, Coyoacan, Mexico City, 1940. Photo: Bernard G. Silberstein. Courtesy Throckmorton Fine Art, New York. (http://www.tate.org.uk/whats-on/tate-modern/exhibition/fridakahlo/frida-kahlo-room-guide/frida-kahlo-room-guide-room-8)

The formula - "souvenir from" - is, as Canclini puts it, "supposedly meant to guarantee the authenticity of the object, [...] a sign of its lack of authenticity" (GARCÍA CANCLINI, 1993: 81). In this case at least, it is blatantly obvious that the arte popular is an object produced for the tourist market, so that the claim to exhibiting it as part of the "national Mexican heritage' manifests a spontaneous expression of the 'soul of the people' is at best misleading - rather, it reveals that this is a deliberate staging proceeding from an utterly unreflective stance towards the object's origins. This is underlined by Kahlo being 'dressed up' with the Tehuana wedding dress. Underneath the lace veil she is in fact still wearing the same dress as on the first photo shown and on others by the same 
photographer - all these photographs were obviously taken in an arranged shooting and are not snapshots of the artist's everyday life.

As García Canclini has shown, the migratory artesanía object, its semantics constantly shifting between traditional object of daily use, coveted collector's item, and tourist souvenir, ${ }^{24}$ positioned within its local context of origin and the urban household, can be described as a blank projection surface. Through its de-contextualization the object is open to all forms of semantic inscriptions:

"Since tourists cannot learn anything about artisans' living conditions, a memory or the nostalgia of an identity unknown by them must be invented for them. Since it destroys the use value of crafts through an undifferentiated exchange of commodities or through the almost hollow symbolic value of 'Indianness', capitalism must create imaginary identities, invent memories, and call attention to them in order to generate meanings that can fill the void left by those that are lost" (GARCÍA CANCLINI, 1993: 81). ${ }^{25}$

Canclini de-privatizes the private dwelling that is visited by guests, characterizing it instead as a "mini-museum, a place of conservation and exhibition" (GARCíA CANCLINI, 1993: 81), where the resident's self-understanding is to find expression - through the things put on display. Exhibiting 'private' things can manifest the owner's 'personal' connection to the nostalgically glorified past (GARCíA CANCLINI, 1993: 82), and at the same time imply an overcoming of this past historical time, its respective 'level of development', and the attainment of 'modernity'. ${ }^{26}$ During the process of this overcoming through appropriation, objects become symbols charged with meaning (GARCÍA CANCLINI, 1993: 82). Artesanía in the 1930s and 1940s in Mexico are to signify the creation of national identity, including in the arts, on the one hand, while on the other they also point to the cosmopolitan aspirations of the artists, who wish to show off their urbanity and openness in the appropriating display of indigenous objects. As if in a souvenir shop, the objects, disconnected from the context of their production, are presented as aesthetic forms in themselves, the indigenous producers excluded from the cultural modernity their products are advancing; indeed, their backwardness is the very prerequisite for staging modernity by those on the other side of the social hierarchy. ${ }^{27}$ This anchoring in ahistorical distant past is, despite all indigenistic rhetoric, the condition for modern progress as propagated by globally active elites under the banner of national unity. The artist posing here thus becomes a tourist in her own country: seeking the 'picturesque' in the 'indigenous', she claims the decontextualized artesanía object to be an inherent characteristic of herself, detaches it from its social environment, and turns it into an object for idealizing her own social class.

Indigenous and popular crafts and costumes were thus used to convey a message of an ethnicized nation that was regarded as modern, made possible in particular by this revaluating of the 'traditional' as modern. Here a blend was sought and achieved between the national and the transnational, the local and the cosmopolitan by urban elites mediating between these contradictive opposites. The indigenous itself was in effect left behind and indeed still taken as a synonym for backwardness.

51 The transformation of the indigenous object and everything related to it into consumer goods, usable in a newly emerging tourism industry, is just one part of the 'modernization of the tradition' - it was not tradition itself that was displayed at the Exposición de Arte Popular in 1921, nor at the 1940 New York World's Fair, nor in the Twenty Centuries of Mexican Art exhibition at the MoMA in the same year; contrary to this notion, it was the tradition-as-modernity that was displayed, a distinctive and unique form of radical 
aesthetic modernism, driven by a new self-confident, nationalistic strategy of claiming modernness for a formerly marginalized setting of modernism, or in other words, the construction - as the historian Partha Chatterjee has put it - of "an aesthetic form that was modern and national, and yet recognizably different from the Western" (CHATTERJEE, 2005: 242).

Miriam Oesterreich, Ph.D.

Post-doc at the Technische Universität Darmstadt, Germany with the habilitation project The 'Folkloristic Modernity' - Mexican Indigenism between National-identitarian Definitions and Transregional Entanglements. Recent publications include Bilder konsumieren. Inszenierungen ,exotischer' Körper in früher Bildreklame. München: Wilhelm Fink, 2018; co-editor of Gottfried Lindauer - Painting New Zealand, RIHA special issue 2018.

\section{BIBLIOGRAFÍA}

ALBERS, Anni (1970), Pre-Columbian Mexican Miniatures. The Josef and Anni Albers Collection, New York.

ADES, Dawn (2015), “Henry Moore and World Sculpture”, in: Henry Moore: Sculptural Process and Public Identity, Tate Research Publication, https://www.tate.org.uk/art/researchpublications/henry-moore/dawn-ades-henrymoore-and-world-sculpture-r1151458, (accessed 06 July 2016).

ANDERSON, Benedict (1983), Imagined Communities. Reflections on the Origin and Spread of Nationalism, London.

ANONYMOUS AUTHOR (1940), "Foreword of the Museum of Modern Art”, in: Twenty Centuries of Mexican Art, exh.cat. MoMA New York, 11-12.

ANONYMOUS AUTHOR (2002), Se exhibirán imágenes inéditas de los judas de Diego Rivera, http://www.jornada.unam.mx/2002/08/09/02an1cul.php?printver=1, 09 August 2002 (accessed 15 June 2017).

BARNET-SANCHEZ, Holly (1993): “The Necessity of Pre-Columbian Art in the United States: Appropriations and Transformations of Heritage, 1933-1945”, in: Elisabeth Hill Boone, ed., Collecting the Pre-Columbian Past. A Symposium at Dumbarton Oaks, 6th and 7th October 1990, Washington, DC, 177-207.

BLUME, Eugen et al., eds. (2015), Black Mountain. Ein interdisziplinäres Experiment, 1933-1957, exh. cat. Hamburger Bahnhof - Museum für Gegenwart Berlin, Leipzig.

BRAUN, Barbara (1993), “Diego Rivera's Collection: Pre-Columbian Art as a Political and Artistic Legacy", in: Elisabeth Hill Boone, ed., Collecting the Pre-Columbian Past. A Symposium at Dumbarton Oaks, 6th and 7th October 1990, Washington, DC, 251-270.

BRAUN, Barbara (1989), “Henry Moore and Pre-Columbian Art”, in: Res. Anthropology and Aesthetics, nos.17/18, 158-197. 
CASTRO LEAL, Antonio (1940), "Introduction”, in: Twenty Centuries of Mexican Art, exh.cat. MoMA New York, New York, 14-17.

CHATTERJEE, Partha (2005), “Whose Imagined Community?”, in: Philip Spencer; Howard Wollman, eds., Nations and Nationalism. A Reader, Edinburgh, 237-247.

CANO, Gabriela (2014), “Frances Toor”, in: Salvador Albiñana, ed., México Ilustrado. Libros, revistas, carteles, 1920-1950, Barcelona/Mexico City, 92-93.

COLLADO HERRERA, María del (2005), Dwight W. Morrow. Reencuentro y revolución en las relaciones entre México y Estados Unidos, 1927-1930, Mexico City.

DANILOVITZ, Brenda (2007), Anni y Josef Albers. Viajes por Latinoamérica, exh.cat. Museo Nacional Centro de Arte Reina Sofía, Madrid, Ostfildern.

DELPAR, Helen (1992), The Enormous Vogue of Things Mexican. Cultural Relations between the United States and Mexico, 1920-1935, Tuscaloosa, University of Alabama Press.

FABIAN, Johannes (2002), Time and the Other. How Anthropology makes its Object, New York.

FLORES, Tatiana (2013), Mexico's Revolutionary Avant-gardes: From Estridentismo to ¡30-30!, New Haven, Conn. [et al.].

FLORES OLMEDO, Diego (2016), “Máscaras Mexicanas: el arte prehispánico y su exhibición como ejercicio de modernidad (1945)”, in: Dafne Cruz Porchini; Claudia Garay Molina; Mireida Velázquez Torres, eds., La Recuperación de la Memoria Histórica de Exposiciones de Arte Mexicano (1930-1950), Mexico City, 81-95.

Ford News, April 1939, vol. 19, nr. 4, special issue: The New York World's Fair 1939.

GARCÍA CANCLINI, Néstor (1993), Transforming Modernity. Popular Culture in Mexico, Austin.

GARZA USABIAGA, Daniel (2012), “Anthropology in the Journals DYN and El hijo pródigo. A Comparative Analysis of Surrealist Inspiration”, in: Dawn Ades; Rita Eder et al., eds., Surrealism in Latin America - Vivísimo Muerto, Los Angeles, 95-110.

GARZA USABIAGA, Daniel (2016), “La Exposición Internacional del Surrealismo como fracaso (1940). Una reconsideración”, in: Dafne Cruz Porchini; Claudia Garay Molina; Mireida Velázquez Torres, eds., La Recuperación de la Memoria Histórica de Exposiciones de Arte Mexicano (1930-1950), Mexico City, 33-44.

GONZÁLEZ, Víctor M.(2015), “La Exposición de Arte Popular o del surgimiento de la vanguardia, México 1921", in: Historias, Revista de la Dirección de Estudios Históricos, no. 90, 59-80.

GREET, Michele (2009), Beyond National Identity: Pictorial Indigenism as a Modernist Strategy in Andean art, 1920-1960, University Park, Pa.

GREET, Michele (2007), "Manifestations of Masculinity: The Indigenous Body as a Site for Modernist Experimentation in Andean Art”, in: Brújula - revista interdisciplinaria sobre estudios latinoamericanos. Art and Encounters, vol. 6, no. 1, 57-74.

HEDRICK, Tace (2003), Mestizo Modernism. Race, Nation and Identity in Latin American Culture,1900-40, Rutgers University Press.

HINKSON, Lauren, ed. (1984), Josef Albers in Mexico, exh. cat. Solomon R. Guggenheim Museum, New York, New York.

HOBSBAWM, Eric (1984), "Introduction. Inventing Traditions“, in: Eric Hobsbawm; Terence Ranger, eds., The Invention of Tradition. Cambridge [et al.], 1-14.

INGLE, Marjorie (1984), Mayan Revival Style: Art Deco Mayan Fantasy, Salt Lake City. 
LÓPEZ, Rick A. (2002): “The Morrows in Mexico. Nationalist Politics, Foreign Patronage, and the Promotion of Mexican Popular Arts", in: Casa Mañana. The Morrow Collection of Mexican Popular Arts, ed. Susan Danly, Amherst, Mass., 47-64.

LÓPEZ, Rick A. (2010), Crafting Mexico. Intellectuals, Artisans, and the State after the Revolution, Durham, Duke University Press.

LÓPEZ, Rick A. (2006), “The Noche Mexicana and the Exhibition of Popular Arts: Two Ways of Exalting Indiannes”, in: Mary Kay Vaughan; Stephen E. Lewis, eds., The Eagle and the Virgin. Nation and Cultural Revolution in Mexico, 1920-1940, Durham, Duke University Press, 23-42.

MAJLUF, Natalia (1994), “El Indigenismo en México y Peru. Hacia una Visión Comparativa”, in: Universidad Nacional Autónoma de México. Instituto de Investigaciones Estéticas, ed., XVII. Coloquio Internacional de Historia del Arte: Arte, Historia e Identidad en América. Visiones Comparativas, Mexiko City, 611-628.

MONTENEGRO, Roberto (1940), “Folk Art”, in: Twenty Centuries of Mexican Art, exh.cat. MoMA New York, New York, 109-110.

MONTGOMERY, Harper (2014), “From Aesthetics to Work: Displaying Indian Labor as Modernist Form in Mexico City and New York", in: Modernism/Modernity 21,1, 231-251.

MONTGOMERY, Harper (2017), The Mobility of Modernism. Art and Criticism in 1920s Latin America, Austin.

MURILLO, Gerardo (Dr. Atl) (1922), Las artes populares en México, 2 vols., Mexico City.

NOVELO, Victoria (1976), Artesanías y capitalismo en México, Mexiko City.

NOVO, Salvador (1932), “Nuestras artes populares”, in: Nuestro México 1,5, Mexico City, 56, cited from: Victoria Novelo (1976), Artesanías y capitalismo en México, Mexico City, 35.

RANDALL, Kimberly (2005), “The Traveler's Eye: Chinas Poblanas and European-Inspired Costume in Postcolonial Mexico”, in: Regina A. Root, ed. (2005), The Latin American Fashion Reader, Oxford/New York, 44-65.

REYNOLDS-KAYE, Jennifer, ed. (2017), Small-Great Objects. Anni and Josef Albers in the Americas, exh. cat. Yale University Art Gallery, London/New Haven.

RIVERA, Diego(1925), "Retablos - The True and only Pictoric Expression of Mexican People”, in: Mexican Folkways 3, 7-9.

ROMANDÍA DE CANTÚ, Graciela (n.d.), El arte popular en la casa azul, http:// www.museofridakahlo.org.mx/assets/files/page_files/document/36/El\%20arte\%20popular\% 20en\%20la\%20Casa\%20Azul\%20.pdf (accessed 15.06.2017).

DE LA ROSA, Natalia(2014), “Mexican Folkways”, in: Salvador Albiñana, ed., México Ilustrado. Libros, revistas, carteles, 1920-1950, Barcelona/Mexico City, 82.

SANDOVAL PÉREZ, Margarito (1998): Arte y Folklore en Mexican Folkways, series: Estudios y fuentes del arte en México LXII. Universidad Nacional Autónoma de México, Instituto de Investigaciones Estéticas, Mexico City.

SCHMELZ, Itala; PEÑALOZA, Ernesto (2012), “Introducción”, in: Itala Schmelz, ed., Luis Márquez en el mundo del mañana. La identidad mexicana y la Feria Mundial de Nueva York, 1939-40, exh. cat. Queens Museum of Art, New York, Mexico City, 16-19.

TOOR, Frances (1932), “Mexican Folkways”, in: Mexican Folkways, vol. VII, no. 4, 205-211. 
TENORIO TRILLO, Mauricio (1996), Mexico at the World's Fairs. Crafting a Modern Nation, Berkeley/Los Angeles/London.

VELÁZQUEZ, Mireida(2010), "Facturas y manufacturas de la identidad - el arte popular Mexicano en 1921", in: Facturas y manufacturas de la identidad. Las artes populares en la modernidad Mexicana, exh. cat. Museo de Arte Moderno, Mexico City, Mexico City, 50-71.

WÖRNER, Martin (1999), Vergnügung und Belehrung. Volkskultur auf den Weltausstellungen 1851-1900, Münster/New York/Munich/Berlin.

WYSS, Beat (2010), Bilder von der Globalisierung. Die Weltausstellung von Paris 1889, Berlin.

ZAVALA, Adriana (2010), Becoming Modern, Becoming Tradition: Women, Gender, and Representation in Mexican Art, Penn State University Press.

ZURIÁN DE LA FUENTE, Carla (2014), “Forma. Revista de Artes Plásticas”, in: Salvador Albiñana, ed., México Ilustrado. Libros, revistas, carteles, 1920-1950, Barcelona/Mexico City, 87-89.

\section{NOTAS FINALES}

1. Some of the Judas figures are on show in Rivera's studio house: in 2002 an exhibition on the painter's Judas collection was held, see the review in La Jornada: Anonymous author: Se exhibirán imágenes inéditas de los judas de Diego Rivera, http:// www.jornada.unam.mx/2002/08/09/02an1cul.php?printver=1, 09 August 2002 (accessed 15 June 2017).

2. For a detailed presentation of the handicraft objects from Kahlo's collection in the casa azul, see the text on the website of the Museo Frida Kahlo: ROMANDÍA DE CANTÚ, n.d.

3. For artistic indigenism, see: FLORES, 2013; GREET, 2007; GREET, 2009; HEDRICK, 2003; MAJLUF, 1994; ZAVALA, 2010.

4. My considerations on the cultural reevaluation of handicrafts draw on the works by Rick A. López, Harper Montgomery, and Helen Delpar; see LÓPEZ, 2010; MONTGOMERY, 2017; DELPAR, 1992. See also: NOVELO 1976.

5. Fashion-conscious Mexican women of the upper class in the late nineteenth century considered it particularly fashionable to go on country outings dressed as china poblana or tehuana, or to celebrate national holidays in these costumes. This fashion was copied by intellectuals and artists in the post-revolutionary period: the best-known example is Frida Kahlo, who began wearing regional costumes in 1926; see RANDALL, 2005: 57.

6. On the history, the social and political context of the magazine, and a detailed listing of its range of subjects, see SANDOVAL PÉREZ, 1998.

7. "And whereas formerly only tourists appreciated the marvelous handicraft productions of the Indians, the Government itself is now encouraging handicrafts, together with folk music and every other popular artistic manifestation." (TOOR, 1932: 206)

8. In: Mexican Folkways, October/November 1926, No. 10, 4.

9. For Forma see ZURIÁN DE LA FUENTE, 2014.

10. The pages, conceived and illustrated by Gabriel Fernández Ledesma, were also the starting point for both publications. Idem: Juguetes mexicanos as well as Calzado mexicano. Cactlis y huaraches , both published in 1930 .

11. The Obregón government attempted to gain legitimation through international recognition, in particular from the USA, and a populist appeal to the 'masses'; see GONZÁLEZ, 2015.

12. It was not easy to even assemble handicrafts from the whole national territory. Due to the short preparation time, the curators were unable to travel to all regions and purchase objects 
there, so they had to rely on working with local (political) authorities. Misunderstandings influenced the cooperation; for example, local representatives failed to understand what a regional art object was for the simple reason they were not used to classifying them as art. In the end, many of the exhibited objects were taken from the private collections of the three artists. See VELÁZQUEZ, 2010, 57-62; LÓPEZ, 2010: 79-82.

13. For the popular world exhibitions in the nineteenth century, see WÖRNER, 1999, and WYSS, 2010. For Mexico specifically, see TENORIO TRILLO, 1996.

14. Rick López sees this aspect of 'education in taste' as one of the goals of the presentation: LÓPEZ, 2006: 30.

15. The first edition accompanying the actual exhibition was far slimmer; the catalogue appeared in the intended detailed form the year after.

16. ALBERS, 1970. Albers writes here (no pagination): "At the time of our early visits, preConquest art had not yet found acceptance as an art, and we felt the excitement of discovery. Only such Mexican artists as Diego Rivera and Miguel Covarrubias recognized the greatness of the indigenous art of their native land, while the social élite appreciated almost exclusively the art of the Western European tradition."

17. The US-American businessman and diplomat Dwight D. Morrow was appointed US ambassador to Mexico 1927 to 1930 and implemented a diplomatic strategy that radically fostered US-Mexican relations, mainly founded in cultural and touristic exchange relationships. His policy is responsible for an inclusion of the Mexican art scene of the era into a touristic strategy as well as a popular appraisal of 'authentic' Mexico as well as its products, arte popular. In this sense, the journal Mexican Folkways as well as Frances Toor's other outstandingly popular writings directly addressing wealthy US-American tourists (A Treasury of Mexican Folkways, 1947, which compiled information on 'the Mexican folk' and its traditions in an encyclopaediclike anthology, the mentioned Frances Toor's Motorist Guide to Mexico, 1938) can be assumed a direct outcome of the Morrow politics. On Morrow's cultural politics see: COLLADO HERRERA, 2005; LÓPEZ, 2002; DELPAR, 1992: especially 59-63; LÓPEZ, 2010: chapter: Foreign-Mexican Collaboration, 1920-1940, 95-126. Dwight and Elizabeth Morrow gathered themselves an impressive collection of Mexican handicrafts and fine art. See LÓPEZ, 2010: 118-119.

18. Founded in 1929, the Museum of Modern Art held a large Diego Rivera exhibition in 1931 (https://www.moma.org/calendar/exhibitions/1979?locale=de), in 1933 the exhibition American Sources of Modern Art (Aztec, Mayan, Incan) (https://www.moma.org/calendar/exhibitions/2932? locale=de).

19. "It filled the entire Museum and even extended into the courtyard, where MoMA staged an open-air Mexican market with stalls selling ceramics, leather goods, and other crafts, flanked by a series of giant pre-colonial statues." https://www.moma.org/calendar/exhibitions/2985 (accessed 12 June 2017). See also BARNET-SANCHEZ, 1993.

20. "Bernal Diaz del Castillo, in his admirable history of the discovery and conquest of Mexico, testified to the high development of Mexican folk art at the time of the arrival of the Spaniards. In the great market of Tenochtitlan everything imaginable was to be found: jewelry of gold and silver, beautifully engraved; feather mosaics; cotton textiles in marvelous colors; utensils of carved wood, bone, and copper; pottery from Cholula and the land of the Tarascans, extraordinary both in form and decoration; paper made of maguey fibre painted and cut into magnificent ritual ornaments; deer hides expressly prepared for the paintings that were made in great numbers; objects made of shell and mother- of-pearl, carved with great delicacy; and an innumerable variety of other ornaments, essentially plastic in conception, which were used to adorn brilliant garments. The conqueror could not conceal his amazement at the dazzling riches that surrounded him. The influence of the Spaniards naturally became apparent in these numerous and diverse objects of popular art, but the authentic stamp of the native Mexican 
craftsman remained dominant and is to this day in whatever he makes or decorates." MONTENEGRO, 1940, 109.

21. Rivera writes: "Come floods of cheap manufacturers, substituting with their factors of multiplication the beautiful and familiar objects in peasant homes, and taking these things of the people to hang as 'objects of art' in useless city homes, or to export and sell elsewhere." RIVERA, 1925: 7-8.

He seems to have never seriously considered the contradiction that he himself, like other modernist artists of the time, never lived in the country, collected indigenous but also handicrafts mass-produced for the tourist market, and displayed them in urban living residences and working studios.

22. Natalia Majluf distinguishes the indigenism in America from the primitivism in Europe's avant-garde: "Por lo tanto no se debe utilizar, como se suele, el exotismo de artistas como Gauguin para definir el indigenismo. El primitivismo [...] es un fenómeno relacionado pero muy distinto. Si Gauguin se definió como indio fue para definirse como marginal. Su búsqueda de un taller en el trópico fue la búsqueda de un paraíso primitivo construido en oposición a la civilización europea. El indigenismo, en cambio, [...] busca en lo indio una opción cultural. No es una opción individualista sino un proyecto colectivo. Por lo mismo, el indigenismo no es una forma de escapar de la sociedad sino todo lo contrario, una forma de inscribirse y definirse dentro de sus parámetros." MAJLUF, 1994: 616. This can be strongly doubted in as far as both phenomena were hierarchic cultural appropriations transcending both social and ethnic boundaries, and translated the form repertoires classified as 'primitive' or 'indigenous' into explicitly 'modern' works of art with the aim to lend an enhanced profile to their own aesthetic practice. One of the most prominent film and theatre critics of his time, Francisco Zamora, argued that the "decorative arts of our anonymous artisans, the songs of our unknown musicians" and the "traditional dances of our indigenous collectivities" offered themselves as raw materials that "men of talent" could take as inspiration in the creation of real art (LÓPEZ, 2010: 73) - in this regard he describes a very Western aesthetic primitivism art practice.

23. See FABIAN, 2002: 147: "Nineteenth- century anthropology sanctioned an ideological process by which relations between the West and its Other, between anthropology and its object, were conceived not only as difference, but as distance in Space and Time."

24. See the chapter "From the Market to the Boutique: When Crafts Migrate", in: GARCíA CANCLINI, 1993: 69-85.

25. In connection with the construction of national identity, see HOBSBAWM, 1984; ANDERSON, 1983; as well as the postcolonial position of CHATTERJEE, 2005.

26. See also GARCÍA CANCLINI, 1993: 83: "The organization of space and the change of context and meaning of popular objects is essential to the construction of the bourgeoisie's hegemony. The latter's interest in crafts is not simply economic and is not limited to reducing peasant misery and migrations or providing easy profits for intermediaries; it also seeks political effects: to reorganize the meaning of popular creations and of their institutions - household, market, fiesta - in order to subordinate them to modernity."

27. See the outstanding case studies MONTGOMERY, 2014 and FLORES OLMEDO, 2016 - here 95: "Al haberse entendido el material precolombino como ligado a la identidad de los mexicanos (en sus raíces), la convicción - ingenua si se quiere - del discurso nacionalista antepuso el valor de uso de la pieza al valor de cambio que pudiera alcanzar o merecer del sistema moderno del arte. De este modo, Máscaras Mexicanas, con todo y su potencia como producto de una institución con miras a la empresa privada, se resolvió también como un programa civilizatorio de identidad nacional". 


\section{RESÚMENES}

The Indigenist discourse in post-revolutionary Mexico massively revaluated regional handicrafts as allegedly authentic relics and expressions of a 'pure indigenous sense of art'. Both within and outside Mexico, artesanía became a highly demanded collectible. Exhibited in museums and fairs, it also became a fashionable home accessory for the urban elites. Especially the modernist bohème in Mexico City used artesanía as an anachronistic source, allowing them to establish the collecting and semi-private exhibiting of handicrafts as an Indigenist art practice. From the 1930s onwards, mainly North-American tourists visited Mexico in great numbers, bought artesanía objects as touristic souvenirs and popularized them internationally.

The paper seeks to problematize the relationship between the cultural reevaluation of the rural and indigenous with modernist art practices. The goal is to critically review the appropriation practices and authentication strategies of modernist artists involved in a nationalist discourse.

El discurso indigenista en el México pos-revolucionario otorgaba un nuevo valor a la artesanía regional como vestigio 'auténtico' y expresión de 'un arte netamente indígena'.

Tanto en México como en el extranjero, la artesanía se convirtió en un objeto de colección de alta demanda. Presentada en museos y exposiciones, además se convirtió en un accesorio de hogar de moda para las élites urbanas.

Sobre todo la bohemia modernista de la Ciudad de México usaba la artesanía como una fuente anacrónica que le permitía establecer el coleccionar y la exhibicion semi-privada de arte popular, como estrategia artística indigenista. A partir de los años treinta, fueron sobre todo turistas norteamericanos los que visitaban México comprando objetos de artesanía como souvenirs y los divulgaban internacionalmente.

El ensayo quiere problematizar el vínculo entre la revalorización cultural de lo rural indígena y el arte modernista. El objetivo principal es una revisión crítica de las estrategias de apropiación e autentificación que usaban los artistas modernistas dentro de un discurso nacionalista.

\section{ÍNDICE}

Keywords: Indigenism, Mexican Modernism, handicraft, folklore, collecting and exhibiting

Palabras claves: Indigenismo, modernismo Mexicano, artesanía, folklore, colección y exhibición 